Ana-Gabriela Babucea' Cecilia-Irina Răbonțu ${ }^{2}$ Aniela Bălăcescu ${ }^{3}$
JEL: C10, C12, E24, J20, J61

DOI: $10.5937 /$ industrija45-13755

UDC:314.151.3-054.72(498)"1990/2014"'

Original Scientific Paper

\title{
A territorial analysis of the Gender Differences in Romanian Permanent Emigration
}

\author{
Article history: \\ Received:20 April 2017 \\ Sent for revision:29 April 2017 \\ Received in revised form: 25 May 2017 \\ Accepted:25 May 2017 \\ Available online: 1 July 2017
}

\begin{abstract}
Romanian emigration is a mass phenomenon, which caused intense debate and numerous studies and research, both in terms of causes, and especially its effects, demonstrating a complex and multidimensional nature. Social and economic problems caused by emigration both for the country of origin and for the destination country become acuter. The statistical data shows that the number of women who leave Romania is higher than men, and research studies revealing the feminization of Romanian emigration, with more profound implication if we considered Romanian demographic trend. The aim of the study is to evaluate the assumption that the Romanian permanent emigration is distributed differently by gender and that there is a different concentration at the territorial level, considered the emigrants' departure place. The dataset used regard the distribution of the number of permanent migrants, women, and men, by their origin place both development region and county, for the period 1990-2014.
\end{abstract}

Keywords: emigration, Gini-Struck coefficients, NUTS2, Romania

\section{Teritorijalna analiza polnih razlika unutar permanentne emigracije u Rumuniji}

Apstrakt: Emigracija u Rumuniji je masovna pojava, koja je pokrenula intenzivnu debatu i mnoštvo studija i istraživanja, kako sa aspekta njenih uzroka, tako i sa

\footnotetext{
1 "Constantin Brâncuși" University of Târgu Jiu,Faculty of Economics, Romania

2 "Constantin Brâncuși" University of Târgu Jiu,Faculty of Economics, Romania

3 "Constantin Brâncuși" University of Târgu Jiu,Faculty of Economics, Romania anielabalacescu@yahoo.com
} 
Babucea AG. et al.: A territorial analysis of the Gender Differences in Romanian...

aspekta njenih efekata, demonstrirajući kompleksnost i multidimenzionalnost njene prirode. Socijalni i ekonomski problemi proistekli iz procesa emigracije, shodno zemlji porekla i zemlji krajnje destinacije emigranata, obostrano dobijaju epitet akutnosti. Statistički podaci ukazuju na činjenicu da više žena napušta Rumuniju od muškaraca, dok naučna istraživanja otkrivaju razloge feminizacije rumunske emigracija, uz razmatranje njenih dubljih implikacija na nacionalni demografski trend. Cilj rada je da se proceni pretpostavka da je rumunska emigracija različito distribuirana po polu, te da postoje razlike u njenoj koncentraciji na teritorijalnom nivou, uzevši u obzir mesto odlaska emigranata. Korišćeni set podataka koji se odnosi na distribuciju stalnih migranata (muškaraca i žena), prema teritoriji sa koje potiču (razvijeni i marginalni regioni), obuhvata period 1990-2014. godina.

Ključne reči: emigracija, Gini-Struck koeficijent, NUTS2, Rumunija.

\section{Introduction}

In Romania, since 1989 profound changes have occurred in terms of the demographic trend, and one of the determinants of the dramatic decline in population was migration phenomenon. (Roman M. Voicu C., 2010). The first years, 1990 and 1991, are well known for high emigration, a significant number of Romanians chose to leave definitive the country. It is about the mass emigration of ethnic minorities (German and Hungarian) that had decided this before the events of 1989, or who had already taken steps in this regard and had been refused (Ethno barometer, 2004). Just since 1992, can talk about the permanent migration of Romanian ethnics (Andreescu, G., 2005).

Figure 1 The permanent Romanian emigration after communism
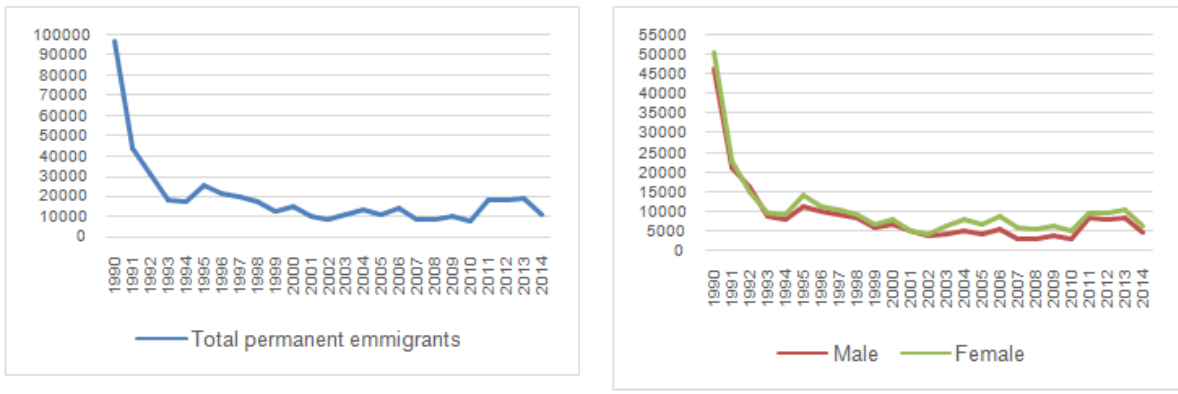

Source: authors' data processing based on National Institute of Statistics, Romania, tempo online 
Babucea AG. et al.: A territorial analysis of the Gender Differences in Romanian...

After 1992, year characterized by the largest number of applications for political asylum, permanent external migration was maintained at a high level as a response to the level of economic and social development of Romania, but the permanent emigration wave from Romania started to decrease steadily until 2007-2008 when the size of definitive migratory flux was the lowest, caused by the entry of Romania into the Union Europe. After the economic and financial crisis, the phenomenon increase somewhat, reaching remarkable levels. Considering the distribution of the permanent emigration by sex, statistical data indicate some prevalence of female migration compared to the male one. (Figure 1.a, b)

In this context, the working assumption throughout this study is that, except the period 1990-1992, external migration of Romanians was due to the disparities of economic regions in which they originate, emigration being the highlight as a cause of low living standards of the population in certain regions of Romania.

Romania has 41 counties plus the city - capital Bucharest, which has a similar status to that of a county corresponding to NUTS-3, organized in eight statistical regions, corresponding to NUTS-2 divisions of the EU but without the administrative capacities, called by position geographic country: NorthWest, North-East, South-West, South-East, South, West, Centre, Bucharest, and Ilfov.

Figure 2. Romania' NUTS 2 Regions

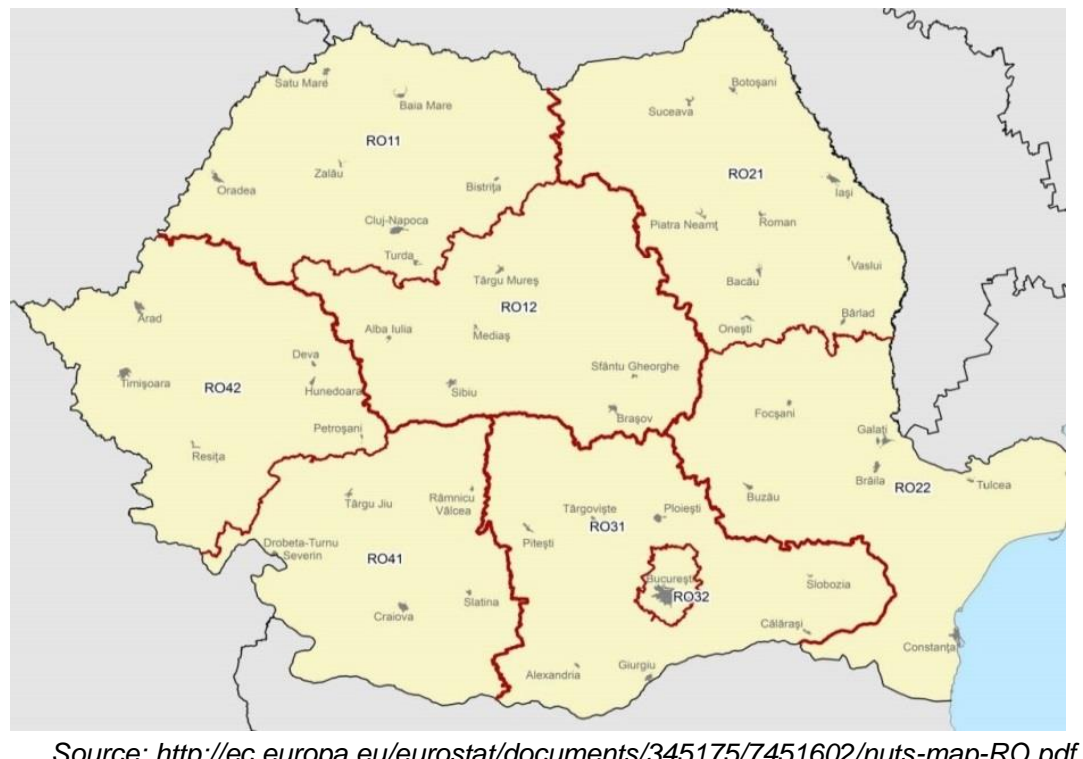


Babucea AG. et al.: A territorial analysis of the Gender Differences in Romanian...

While in the early 90s Romania has had a relatively low level of regional disparities, given that all regions were underdeveloped, disparities between regions have increased rapidly, Bucharest-Ilfov Region standing out significantly since the mid-1990s of the rest of the country. Except for this region, which has a special situation in the country's social and economic context being the Romania capital, the development was done from the WestEast direction, as a result of proximity to western markets which stimulated the growth. Romanian macroeconomic indicators also show that underdeveloped regions are concentrated in the northeast, on the border with Moldova, and in the south of the country, along with the Danube River.

Figure 3 Evolution of Romanian permanent emigrants by region of departure (NUTS2)

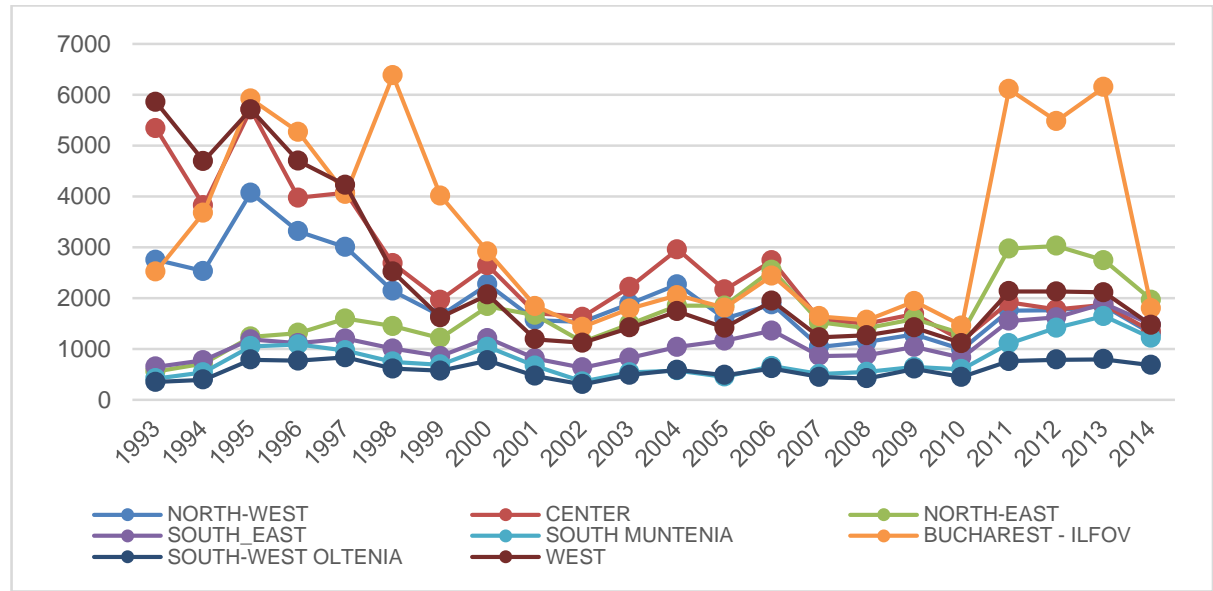

Source: authors' data processing based on National Institute of Statistics, Romania, tempo online

\section{Dataset and methodology}

Firstly, we present a descriptive analysis of the evolution of permanent emigrants by gender, in the spatial distribution by regions and counties of departure, for the period 1993-2014 and we test the significance of differences in the emigration by gender using specific methods with SPSS v. 20.0 for Windows.

For analyzing the spatial concentration of permanent emigrants by sex at the regional level of departure places, we apply Lorenz curve and Gini-Struck coefficient. We intend to detect the influence of regional development and 
Babucea AG. et al.: A territorial analysis of the Gender Differences in Romanian...

hence the impact of the socio-economic conditions in the decision to leave the country permanently.

Table 1 Evolution of Romanian permanent emigrants by region of departure (NUTS2)

\begin{tabular}{|c|c|c|c|c|c|c|c|c|c|c|c|c|c|c|c|c|c|c|c|c|c|c|c|c|c|}
\hline & 1990 & 1991 & 1992 & 1993 & $\mid 1994$ & 1995 & 1996 & $\mid 1997$ & 1998 & 1999 & 2000 & 2001 & 2002 & 2003 & 2004 & 2005 & 2006 & 20072 & 2008 & 2009 & 2010 & 2011 & 2012 & 2013 & \begin{tabular}{l|l|}
3 & 2014
\end{tabular} \\
\hline $\begin{array}{l}\text { NORTH- } \\
\text { WEST }\end{array}$ & & 6754 & 4593 & 2752 & 2532 & 4070 & 3311 & 3003 & 2142 & 1657 & 2271 & 1569 & 1536 & 1893 & 2270 & 1595 & 1876 & $1045 \mid 1$ & 1137 & 1284 & 992 & 1757 & 1766 & 1848 & $\begin{array}{ll}8 & 1301\end{array}$ \\
\hline CENTER & 39681 & 15907 & 710991 & 5338 & 3819 & 5709 & 3971 & 4071 & 2683 & 1964 & 2640 & 1703 & 1628 & 2219 & 2958 & 2164 & 2739 & 15701 & 1504 & 1689 & 1163 & 1921 & 1776 & 1870 & 01345 \\
\hline NORTH-EAST & 1761 & 1949 & 1015 & 558 & 711 & 1241 & 1315 & 1596 & 1450 & 1216 & 1837 & 1667 & 1140 & 1495 & 1853 & 1852 & 2556 & 15221 & 1412 & 1593 & 1302 & 2972 & 3027 & 2742 & \begin{tabular}{l|l|}
2 & 1964
\end{tabular} \\
\hline SOUTH_EAST & 1648 & 1776 & 873 & 652 & 778 & 1186 & 1113 & 1202 & 1005 & 857 & 1213 & 813 & 632 & 826 & 1039 & 1160 & 1360 & 863 & 881 & 1038 & 830 & 1551 & 1620 & 1894 & $\begin{array}{ll}4 & 1481\end{array}$ \\
\hline \begin{tabular}{|c|} 
SOUTH \\
MUNTENIA
\end{tabular} & 84 & 2188 & 614 & 420 & 540 & 1052 & 1087 & 971 & 750 & 90 & 1039 & 668 & 360 & 538 & 578 & 453 & 663 & 507 & 549 & 644 & 602 & 1107 & 1414 & 1646 & $\begin{array}{ll}6 & 1214\end{array}$ \\
\hline \begin{tabular}{|c|} 
BUCHAREST \\
- ILFOV \\
\end{tabular} & 7977 & 4032 & 4381 & 2523 & 3678 & 5916 & 5266 & 4045 & 56376 & 4014 & 2913 & 1841 & $\mid 1431$ & 1792 & 2057 & 1808 & 2440 & 1643 & $\mid 1567$ & 1936 & $\mid 1456$ & 6106 & 479 & 6148 & \begin{tabular}{l|l}
8 & 1797
\end{tabular} \\
\hline \begin{tabular}{|c|} 
SOUTH-WEST \\
OLTENIA
\end{tabular} & 827 & 1040 & 581 & 351 & 396 & 791 & 767 & 835 & 614 & 574 & 772 & 468 & 306 & 489 & 589 & 488 & 617 & 451 & 419 & 607 & 449 & 759 & 791 & 797 & 681 \\
\hline WEST & 32535 & 10514 & \begin{tabular}{ll|}
47104 \\
\end{tabular} & 5852 & 4692 & 5710 & 4696 & 4222 & 2516 & 1622 & 2068 & \begin{tabular}{|l|l|}
8192 \\
\end{tabular} & 21121 & 1421 & 1738 & 1418 & 1946 & 1229 & 1270 & 1420 & 1112 & 2134 & 2128 & 2111 & 11468 \\
\hline
\end{tabular}

Source: Data available on Tempo Online database, $\underline{\text { www.insse.ro }}$

A distinct aspect of the structural approach is provided by the characterization of the degree of uniformity/concentration of the repartitions of permanent emigrants by sex per counties/regions.

In accordance with the data that are available, the territorial analysis of the Romanian emigration phenomena in the year 2014 will have to capture several aspects, with regard to both space, and time location: the proportions that are established between the gender of emigrants and the geographical distribution of their place of departure. In that respect, we use the most frequently resorted method of the Gini-Struck coefficient:

$$
C_{s}=\sqrt{\frac{n \sum g_{i}^{2}-1}{n-1}}
$$

If the value of that coefficient, finally designated by the name Gini-Struck, tends towards 1 , it is indicative of a high degree of concentration of the structure, and if the value of the coefficient tends towards 0 , it indicates a poor degree of concentration of the population analyzed.

In the third part analyzed intra and inter-regional variation appealing to ANOVA. The study results are significant for mitigating the process of leaving the country permanently mainly due to the migration, mainly because Romania has registered structural changes with major demographic 
Babucea AG. et al.: A territorial analysis of the Gender Differences in Romanian...

implications. Firstly we present a descriptive analysis of the evolution of permanent emigrants by gender, in the spatial distribution by regions and counties of departure, for the period 1991-2014 and we test the significance of differences in the emigration by gender using specific methods with SPSS v. 20.0 for Windows.

\section{Analysis of spatial distribution of migration by gender at the level of development regions of Romania}

If we consider the Romanian permanent resident population, the observation of demographic data at the NUTS2 levels between 1993 and 2014, presented in table no.2, reveals a significant demographic decline across Romanian regions, both from men and women. We note demographic growth only in llfov-Bucharest region, around the Romania's capital and in North-East region, and only for women.

Table 2 Changes in Romanian Permanent Resident Population at January, 1st - distribution by sex and regions (NUTS2)

\begin{tabular}{|c|c|c|c|c|c|c|c|c|c|c|c|c|c|}
\hline \multirow{3}{*}{$\begin{array}{r}\text { Regions } \\
\text { NORTH-WEST }\end{array}$} & \multicolumn{5}{|c|}{2014} & \multicolumn{5}{|c|}{1993} & \multicolumn{3}{|c|}{ Changes } \\
\hline & \multirow{2}{*}{\begin{tabular}{|c|} 
Total \\
2841110 \\
\end{tabular}} & \multicolumn{2}{|c|}{ Men } & \multicolumn{2}{|c|}{ Women } & \multirow{2}{*}{\begin{tabular}{c|} 
Total \\
2954889
\end{tabular}} & \multicolumn{2}{|l|}{ Men } & \multicolumn{2}{|c|}{ Women } & \multirow{2}{*}{$\begin{array}{c}\text { Total } \\
-3,85\end{array}$} & \multirow{2}{*}{$\begin{array}{c}\text { Men } \\
-4,92\end{array}$} & \multirow{2}{*}{$\frac{\text { Women }}{-2,8}$} \\
\hline & & 1389464 & 0,49 & 1451646 & 0,51 & & 1461399 & 0,49 & 1493490 & 0,51 & & & \\
\hline NORTH-EAST & 3899889 & 1935176 & 0,50 & 1964713 & 0,50 & 3858147 & 1922274 & 0,50 & 1935873 & 0,50 & 1,08 & 0,67 & 1,49 \\
\hline WEST & 2026166 & 983441 & 0,49 & 1042725 & 0,51 & 2120182 & 1036337 & 0,49 & 1083845 & 0,51 & $-4,43$ & $-5,1$ & $-3,79$ \\
\hline CENTER & 2641067 & 1294768 & 0, & 1346299 & 0,51 & 2704881 & 1340918 & 0,50 & 1363963 & 0,50 & $-2,36$ & $-3,44$ & $-1,3$ \\
\hline SOUTH-WEST OLTENIA & 2237651 & 1097833 & 0,49 & 1139818 & 0,51 & 2442481 & 1202448 & 0,49 & 1240033 & 0,51 & $-8,39$ & $-8,7$ & $-8,08$ \\
\hline SOUTH MUNTENIA & 3300634 & 1611491 & 0,49 & 1689143 & 0,51 & 3564093 & 1754757 & 0,49 & 1809336 & 0,51 & $-7,39$ & $-8,16$ & $-6,64$ \\
\hline SOUTH-EAST & 2900677 & 1421167 & 0,49 & 1479510 & 0,51 & 3002730 & 1493588 & 0,50 & 1509142 & 0,50 & $-3,4$ & $-4,85$ & $-1,96$ \\
\hline ILFOV-BUCHAREST & 2498984 & 1173311 & 0,47 & 1325673 & 0,53 & 2471342 & 1172678 & 0,47 & 1298664 & 0,53 & 1,12 & 0,05 & 2,08 \\
\hline ROMANIA & 22346178 & 10906651 & 0,49 & 11439527 & 0,51 & 23118745 & 11384399 & 0,49 & 11734346 & 0,51 & $-3,34$ & $-4,2$ & $-2,51$ \\
\hline
\end{tabular}

Source: Authors calculations from data available on Tempo Online database, www.insse.ro

But, it is worth noting that although the resident population has decreased considerably in the year 2014 compared with 1993, the gender structure of the population was maintained at the level of all regions and Romania, respectively with a sensitive superiority of women to men. 
Babucea AG. et al.: A territorial analysis of the Gender Differences in Romanian...

Figure 3 Romanian permanent resident population at January, $1^{\text {st }} 2014$ distribution by sex and regions (NUTS2)
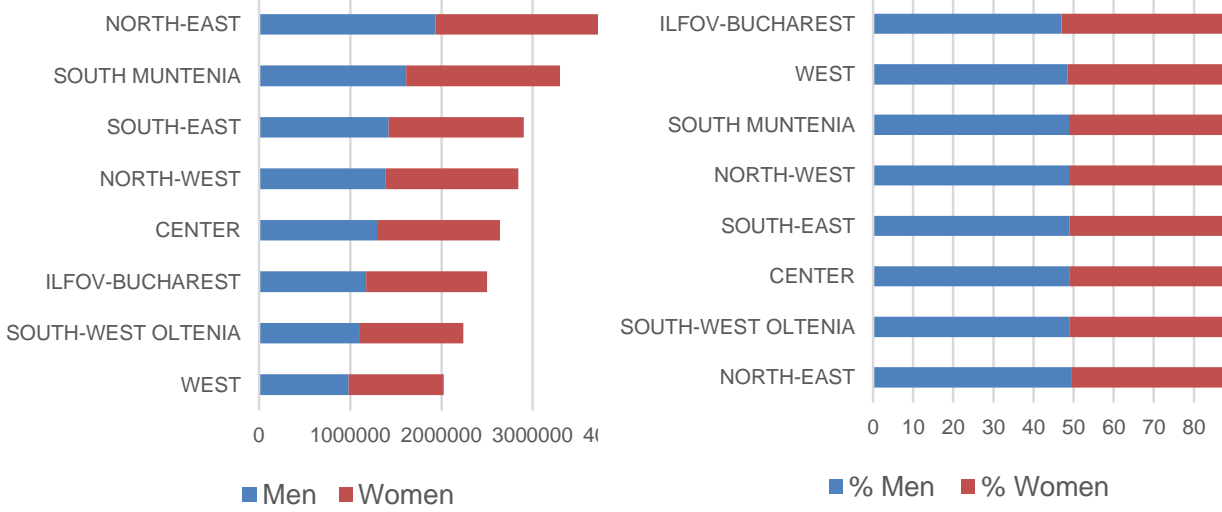

Source: authors' data processing based on National Institute of Statistics, Romania, tempo online

This decline is because a negative demographic growth affected Romania after 1990, in a large part, but, on the same time, emigration phenomenon hit Romania in various forms, permanent emigration being one of them. Comparing 2014 with 1993 in terms of Romania's population which has permanently residing abroad, by region of origin, reveals a significant decrease nationwide, but with alarming increase of the share of women compared to men both at the level of all regions, but, at country level. (See table no. 3). The situation is even more worrying as national statistics indicate a higher proportion of male permanently immigrants in Romania.

Table 3 Distribution of Permanent Emigrants by sex and departure regions, in the year 2014 comparing with 1993

\begin{tabular}{|c|c|c|c|c|c|c|c|c|c|c|c|c|c|}
\hline \multirow{3}{*}{$\begin{array}{l}\text { Development region } \\
\text { RTH-WEST }\end{array}$} & \multicolumn{5}{|c|}{2014} & \multicolumn{5}{|c|}{1993} & \multicolumn{3}{|c|}{ Changes (persons) } \\
\hline & \multirow{2}{*}{\begin{tabular}{|c|} 
Total \\
1301 \\
\end{tabular}} & \multicolumn{2}{|c|}{ Men } & \multicolumn{2}{|c|}{ Women } & \multirow{2}{*}{\begin{tabular}{|r|r|} 
Total \\
2752 \\
\end{tabular}} & \multicolumn{2}{|c|}{ Men } & \multicolumn{2}{|c|}{ Women } & \multirow{2}{*}{\begin{tabular}{|c|} 
Total \\
-1451 \\
\end{tabular}} & \multirow{2}{*}{$\begin{array}{c}\text { Men } \\
-768 \\
\end{array}$} & \multirow{2}{*}{$\frac{\text { Women }}{-683}$} \\
\hline & & 577 & 0,44 & 724 & 0,56 & & 1345 & 0,49 & 1407 & 0,51 & & & \\
\hline NORTH-EAST & 1964 & 815 & 0,41 & 1149 & 0,59 & 558 & 281 & 0,50 & 277 & 0,50 & 1406 & 534 & 872 \\
\hline WEST & 1468 & 640 & 0,44 & 828 & 0,56 & 5852 & 2695 & 0,46 & 3157 & 0,54 & -4384 & -2055 & -2329 \\
\hline CENTER & 1345 & 593 & 0,44 & 752 & 0,56 & 5338 & 2582 & 0,48 & 2756 & 0,52 & -3993 & -1989 & -2004 \\
\hline SOUTH-WEST OLTENIA & 681 & 275 & 0,40 & 406 & 0,60 & 351 & 175 & 0,50 & 176 & 0,50 & 330 & 100 & 230 \\
\hline SOUTH MUNTENIA & 1214 & 521 & 0,43 & 693 & 0,57 & 420 & 197 & 0,47 & 223 & 0,53 & 794 & 324 & 470 \\
\hline SOUTH-EAST & 1481 & 590 & 0,40 & 891 & 0,60 & 652 & 325 & 0,50 & 327 & 0,50 & 829 & 265 & 564 \\
\hline ILFOV-BUCHAREST & 1797 & 765 & 0,43 & 1032 & 0,57 & 2523 & 1151 & 0,46 & 1372 & 0,54 & -726 & -386 & -340 \\
\hline ROMANIA & 11251 & 4776 & 0,42 & 6475 & 0,58 & 18446 & 8751 & 0,47 & 9695 & 0,53 & -7195 & -3975 & -3220 \\
\hline
\end{tabular}

Source: Authors calculations from data available on Tempo Online database, www.insse.ro 
Babucea AG. et al.: A territorial analysis of the Gender Differences in Romanian...

While nationwide in the year 2014 decreased the number of permanent emigrants, there are Romanian regions where the phenomenon is manifested aggressive, especially in the regions considered with the standard of living very low, as North-East region on the border with Moldova, and South Muntenia, South-West Oltenia or South-East, regions in the south of the country, along the Danube River, regions where permanent emigration was not an option in the early 90 s.

Figure 4 Romanian definitive emigrants by sex and departure regions, in the year 2014- distribution by sex and regions (NUTS2)
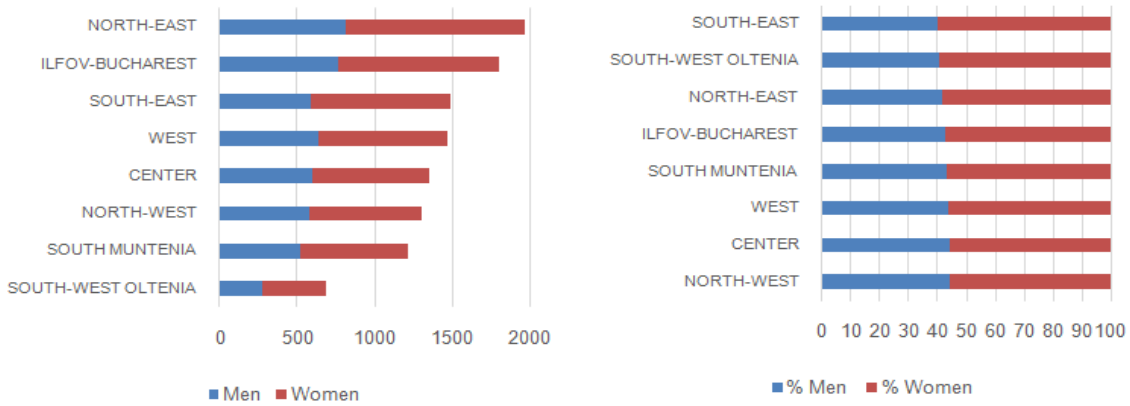

Figure 5 Correlation between definitive emigrants and permanent resident population by gender on the year 2014, at the level of Romanian regions (NUTS2)
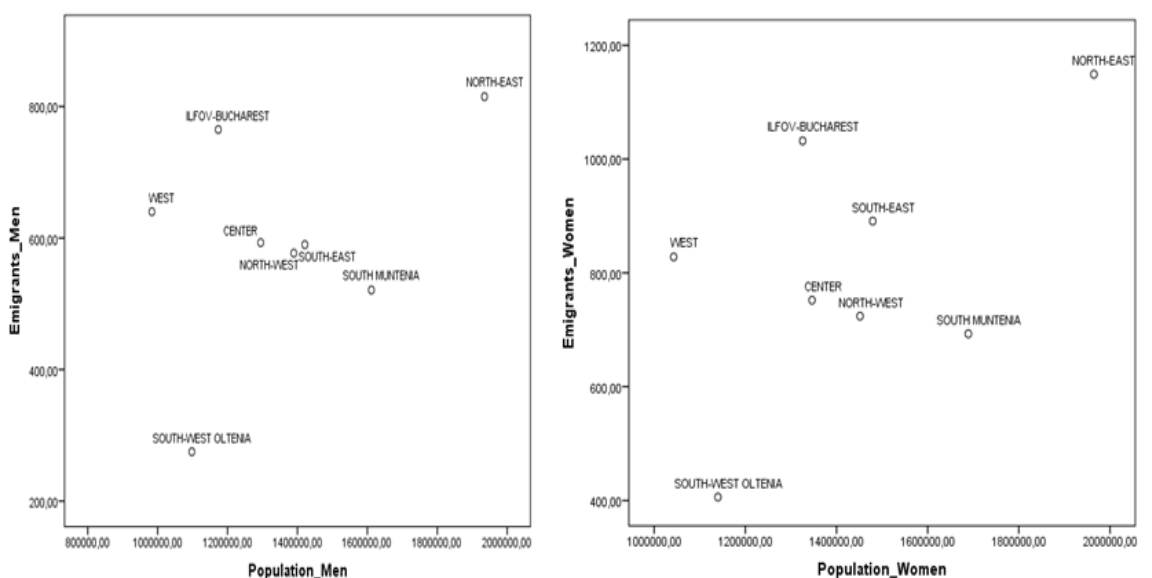

Source: authors' data processing based on National Institute of Statistics, Romania, tempo online 
Babucea AG. et al.: A territorial analysis of the Gender Differences in Romanian...

It is obvious that the number of migrants from a given region is, to some extent, determined by the resident population of the same kind from the region of departure considered, creating a direct link between the two variables. The figure above presents the scatterplots for the links between resident population and emigrated population, during the year 2014, at the level of Romanian 8th regions, by gender. We note the linear relationship, with moderate intensity, higher among women, and the special situation of West and Ilfov-Bucharest regions.

If it is envisaged and the resident population in the regions, in terms of rates of emigration per 1,000 habitants, is remarkable the West region which remains at the first position between the regions of Romania, even if its migration has decreased, while the regions South Muntenia and South -West Oltenia with high levels of emigration definitive 2014 compared to 1993 still remain to claim its last position in the hierarchy both in terms of total population, and gender distribution.

The South-East, the region with the most interesting change of position regarding emigration, being on the 3rd place, especially amid women.

Table 4. The Rate of emigration per 1000 habitants at the level of regions, by sex, in the year 2014 comparing with 1993

\begin{tabular}{|c|c|c|c|c|c|c|c|c|c|c|c|c|c|c|c|}
\hline \multirow[b]{3}{*}{ Regions } & \multicolumn{5}{|c|}{ Total emigrants } & \multicolumn{5}{|c|}{ Men } & \multicolumn{5}{|c|}{ Women } \\
\hline & \multicolumn{2}{|c|}{2014} & \multicolumn{2}{|c|}{1993} & \multirow{2}{*}{\begin{tabular}{|c|}
$2014 / 19993$ \\
$\begin{array}{c}\text { Change in } \\
\text { rank }\end{array}$ \\
\end{tabular}} & \multicolumn{2}{|l|}{2014} & \multicolumn{2}{|l|}{1993} & \multirow{2}{*}{\begin{tabular}{|c|}
$2014 / 1993$ \\
Change in \\
rank
\end{tabular}} & \multicolumn{2}{|c|}{2014} & \multicolumn{2}{|l|}{1993} & \multirow{2}{*}{\begin{tabular}{|c|}
$2014 / 1993$ \\
Change in \\
rank
\end{tabular}} \\
\hline & $\begin{array}{c}\text { Rate per } \\
1000 \\
\text { habitants }\end{array}$ & Rank & $\begin{array}{c}\text { Rate per } \\
1000 \\
\text { habitants }\end{array}$ & Rank & & $\begin{array}{c}\text { Rate per } \\
1000 \\
\text { habitants }\end{array}$ & Rank & $\begin{array}{c}\text { Rate per } \\
1000 \\
\text { habitants }\end{array}$ & Rank & & \begin{tabular}{|c} 
Rate per \\
1000 \\
habitants
\end{tabular} & Rank & \begin{tabular}{|c} 
Rate per \\
1000 \\
habitants
\end{tabular} & Rank & \\
\hline WEST & \begin{tabular}{|l|l|}
0,7245 \\
\end{tabular} & 1 & 2,7601 & 1 & 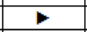 & 0,6508 & 2 & 2,7404 & 1 & $\mathbf{\nabla} 1$ & 0,7941 & 1 & 2,9128 & 1 & 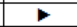 \\
\hline $\begin{array}{l}\text { |lLFOV- } \\
\text { BUCHAREST }\end{array}$ & 0,7191 & 2 & 1,0209 & 3 & $\Delta 1$ & 0,652 & 1 & 0,981 & 3 & $\Delta 2$ & 0,7785 & 2 & 1,0565 & 3 & $\mathbf{\Delta} 1$ \\
\hline \begin{tabular}{|l|} 
SOUTH-EAST \\
\end{tabular} & 0,5106 & 3 & 0,2171 & 5 & $\Delta 2$ & 0,4152 & 6 & 0,2287 & 5 & $\mathbf{\nabla} 1$ & 0,6022 & 3 & 0,2167 & 5 & $\Delta 2$ \\
\hline NORTH-EAST & 0,5036 & 4 & 0,1446 & 6 & $\Delta 2$ & 0,4212 & 3 & 0,1452 & 7 & $\Delta 4$ & 0,5848 & 4 & 0,1431 & 6 & $\Delta 2$ \\
\hline \begin{tabular}{|l} 
CENTER \\
\end{tabular} & 0,5093 & 5 & 1,9735 & 2 & 73 & 0,458 & 4 & 1,9942 & 2 & 2 & 0,5586 & 5 & 2,0206 & 2 & $\sqrt{3}$ \\
\hline NORTH-WEST & 0,4579 & 6 & 0,9313 & 4 & $\mathbf{\nabla} 2$ & 0,4153 & 5 & 0,968 & 4 & $\nabla 1$ & 0,4987 & 6 & 0,9421 & 4 & $\mathbf{\nabla} 2$ \\
\hline $\begin{array}{l}\text { SOUTH } \\
\text { MUNTENIA }\end{array}$ & 0,3678 & 7 & 0,1178 & 8 & $\Delta 1$ & 0,3233 & 7 & 0,1222 & 8 & $\Delta 1$ & 0,4103 & 7 & 0,1232 & 8 & $\Delta 1$ \\
\hline $\begin{array}{l}\text { SOUTH-WEST } \\
\text { OLTENIA }\end{array}$ & 0,3043 & 8 & 0,1437 & 7 & $\nabla 1$ & 0,2505 & 8 & 0,1594 & 6 & $\mathbf{v} 2$ & 0,3562 & 8 & 0,1419 & 7 & $\mathbf{\nabla} 1$ \\
\hline
\end{tabular}

Source: Authors calculations from data available on Tempo Online database, www.insse.ro

The degree of permanent Romanian emigrants' concentration according to the distribution of the resident population at the level of the development regions can be assessed using the Lorenz curve for whose graphical representation was calculated the cumulative shares for the years 2014, both for men and women. 
Babucea AG. et al.: A territorial analysis of the Gender Differences in Romanian...

Table 5. Algorithm for calculating the cumulative shared used for Lorenz curve graphic representation, for men in the year 2014

\begin{tabular}{|c|c|c|c|c|c|c|c|}
\hline \multirow{2}{*}{ Regions } & \multicolumn{2}{|c|}{ Resident population } & \multicolumn{2}{|c|}{ Permanent emigrants } & \multirow{2}{*}{$\begin{array}{c}\text { \%Permanent } \\
\text { emigrants (Men) } \\
\text { l\%Resident } \\
\text { population (Men) }\end{array}$} & \multirow{2}{*}{$\begin{array}{l}\text { Cumulative } \% \text { of } \\
\text { Resident } \\
\text { population (Men) }\end{array}$} & \multirow{2}{*}{$\begin{array}{c}\text { Cumulative } \% \text { of } \\
\text { Resident } \\
\text { population (Men) }\end{array}$} \\
\hline & No. of Men & $\%$ & No. of Men & $\%$ & & & \\
\hline $\begin{array}{l}\text { SOUTH-WEST } \\
\text { OLTENIA }\end{array}$ & 1097833 & 10,06572 & 275 & 5,75795645 & 0,5720362 & 10,06572 & 5,757956 \\
\hline SOUTH MUNTENIA & 1611491 & 14,775305 & 521 & 10,9087102 & 0,7383069 & 24,841026 & 16,66667 \\
\hline .NORTH-WEST & 1389464 & 12,739603 & 577 & 12,0812395 & 0,9483215 & 37,580629 & 28,74791 \\
\hline SOUTH-EAST & 1421167 & 13,030278 & 590 & 12,3534338 & 0,948056 & 50,610907 & 41,10134 \\
\hline \begin{tabular}{|l} 
NORTH-EAST \\
\end{tabular} & 1935176 & 17,743082 & 815 & 17,0644891 & 0,9617545 & 68,353989 & 58,16583 \\
\hline CENTER & 1294768 & 11,871362 & 593 & 12,4162479 & 1,0458992 & 80,225351 & 70,58208 \\
\hline \begin{tabular}{|l|} 
ILFOV- \\
BUCHAREST
\end{tabular} & 1173311 & 10,757757 & 765 & 16,0175879 & 1,4889338 & 90,983107 & 86,59966 \\
\hline WEST & 983441 & 9,0168925 & 640 & 13,400335 & 1,4861367 & 100 & 100 \\
\hline Total - ROMANIA & 10906651 & 100 & 4776 & 100 & 8,1894449 & & \\
\hline
\end{tabular}

Source: Authors calculations from data available on Tempo Online database, www.insse.ro

Table 6. Algorithm for calculating the cumulative shared used for Lorenz curve graphic representation, for women in the year 2014

\begin{tabular}{|c|c|c|c|c|c|c|c|}
\hline \multirow[b]{2}{*}{ Regions } & \multicolumn{2}{|c|}{ Resident population } & \multicolumn{2}{|c|}{ Permanent emigrants } & \multirow{2}{*}{\begin{tabular}{|c|}
$\%$ Permanent \\
emigrants (Women) \\
/\%Resident \\
population (Women) \\
\end{tabular}} & \multirow{2}{*}{$\begin{array}{l}\text { Cumulative } \% \text { of } \\
\text { Resident } \\
\text { population } \\
\text { (Women) } \\
\end{array}$} & \multirow{2}{*}{$\begin{array}{c}\text { Cumulative } \% \text { of } \\
\text { Resident } \\
\text { population } \\
\text { (Women) }\end{array}$} \\
\hline & $\begin{array}{l}\text { No. of } \\
\text { women }\end{array}$ & $\%$ & $\begin{array}{l}\text { No. of } \\
\text { women }\end{array}$ & $\%$ & & & \\
\hline $\begin{array}{l}\text { SOUTH-WEST } \\
\text { OLTENIA }\end{array}$ & 1139818 & 9,96385602 & 406 & 6,27027027 & 0,62930157 & 9,963856 & 6,27027 \\
\hline SOUTH MUNTENIA & 1689143 & 14,7658465 & 693 & 10,7027027 & 0,64530947 & 24,7297 & 16,97297 \\
\hline \begin{tabular}{|l} 
NORTH-WEST \\
\end{tabular} & 1451646 & 12,689738 & 724 & 11,1814672 & 0,78447492 & 37,41944 & 28,15444 \\
\hline CENTER & 1346299 & 11,7688345 & 752 & 11,6138996 & 0,87857236 & 49,18828 & 39,76834 \\
\hline NORTH-EAST & 1964713 & 17,1747748 & 1149 & 17,7451737 & 0,91986084 & 66,36305 & 57,51351 \\
\hline SOUTH-EAST & 1479510 & 12,9333145 & 891 & 13,7606178 & 0,94724216 & 79,29636 & 71,27413 \\
\hline $\begin{array}{l}\text { ILFOV- } \\
\text { BUCHAREST }\end{array}$ & 1325673 & 11,5885298 & 1032 & 15,9382239 & 1,22445973 & 90,88489 & 87,21236 \\
\hline WEST & 1042725 & 9,1151059 & 828 & $\mid 12,7876448$ & 1,24899808 & 100 & 100 \\
\hline ROMANIA - Total & 11439527 & 100 & 6475 & 100 & & & \\
\hline
\end{tabular}

To assess the concentration of the gender emigration in the NUTS2 regions of Romania in 2014, the year for which data are available for all of them, and for compared each other, first the Lorenz curves were built. The data required graphical representations are shown in tables 5 and 6 . The graphical representations in Figure 6 , a) for men and b) for women, show a moderate level of concentration in both of the genders, if we consider the residence population of the same gender of each region as a point of reference in assessing the permanent emigration population by gender, but that indicates a difference over the year 2014, even if it is not significant. 
Babucea AG. et al.: A territorial analysis of the Gender Differences in Romanian...

Figure 5 Lorenz Curves

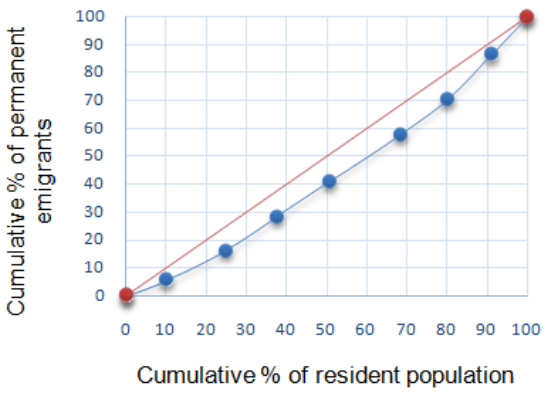

a) Men (year 2014)

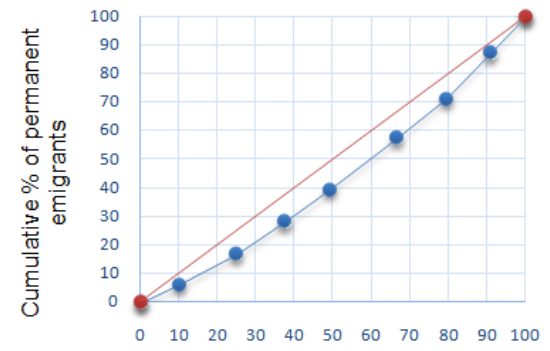

Cumulative $\%$ of resident population

b) Women (year 2014)

Concentration coefficients for each variable considered were calculated based on the data in Tables 5 and 6 , the territorial concentration coefficients (territorial distributions) were determined using the concentration Gini-Struck, and presented in the Table 7.

Table 7 Algorithm for calculating Gini-Struck coefficients for Permanent emigrants in the year 2014

\begin{tabular}{|l|c|c|c|c|c|c|c|c|c|}
\hline \multirow{2}{*}{$\begin{array}{l}\text { Development } \\
\text { regions }\end{array}$} & \multicolumn{3}{|c|}{ Permanent emigrants } & \multicolumn{3}{c|}{ Permanentemigrants - men } & \multicolumn{3}{c|}{$\begin{array}{c}\text { Permanent } \\
\text { emigrants - women }\end{array}$} \\
\cline { 2 - 10 } & No. & $g_{i}$ & $g_{i}^{2}$ & No. & $g_{i}$ & $g_{i}^{2}$ & No. & $g_{i}$ & $g_{i}^{2}$ \\
\hline NORD-WEST & 1301 & 0,11563417 & 0,0133713 & 577 & 0,1208124 & 0,01459563 & 724 & 0,11181467 & 0,01250252 \\
\hline NORD-EAST & 1964 & 0,17456226 & 0,030472 & 815 & 0,17064489 & 0,02911968 & 1149 & 0,17745174 & 0,03148912 \\
\hline WEST & 1468 & 0,13047729 & 0,0170243 & 640 & 0,13400335 & 0,0179569 & 828 & 0,12787645 & 0,01635239 \\
\hline CENTER & 1345 & 0,11954493 & 0,014291 & 593 & 0,12416248 & 0,01541632 & 752 & 0,116139 & 0,01348827 \\
\hline SOUTH-WEST OLTENIA & 681 & 0,06052795 & 0,0036636 & 275 & 0,05757956 & 0,00331541 & 406 & 0,0627027 & 0,00393163 \\
\hline SOUTH MUNTENIA & 1214 & 0,10790152 & 0,0116427 & 521 & 0,1090871 & 0,0119 & 693 & 0,10702703 & 0,01145478 \\
\hline SOUTH-EAST & 1481 & 0,13163274 & 0,0173272 & 590 & 0,12353434 & 0,01526073 & 891 & 0,13760618 & 0,01893546 \\
\hline BUCHAREST+ILFOV & 1797 & 0,15971914 & 0,0255102 & 765 & 0,16017588 & 0,02565631 & 1032 & 0,15938224 & 0,0254027 \\
\hline \multicolumn{1}{c|}{ Total } & 11251 & 1 & 0,1333023 & 4776 & 1 & 0,13322098 & 6475 & 1 & 0,13355686 \\
\hline
\end{tabular}

Source: Authors calculations from data available on Tempo Online database, www.insse.ro

The values obtained from the calculations for concentration coefficients, presented in the table below, reveal an insignificant concentration at the level of regions, both for men and women and also for the total permanent emigrants, but higher for women. 
Babucea AG. et al.: A territorial analysis of the Gender Differences in Romanian...

Table 8 Gini-Struck coefficients for Permanent emigrants, in the year 2014

\begin{tabular}{|l|c|}
\hline \multicolumn{1}{|c|}{ Variables } & Gini-Struck coefficient: $C_{s}=\sqrt{\frac{n \sum g_{i}^{2}-1}{n-1}}$ \\
\hline Total permanent emigrants & 0,0974081 \\
\hline Total permanent emigrants - men & 0,0969299 \\
\hline Total permanent emigrants - women & 0,0988902 \\
\hline
\end{tabular}

Source: authors' data processing based on National Institute of Statistics, Romania, tempo online

\section{Analysis of spatial distribution of migration by gender at the level of counties}

An analysis at the county level was necessary for identification the existing gender differences. Based on data from table 9 we analyzed intra and interregional variation appealing to ANOVA procedure to verify the hypothesis that the region / county of origin influences the permanent emigration by gender.

Table 9 Permanent emigrants, by gender and county of departure, in 2014

\begin{tabular}{|c|c|c|c|c|}
\hline \multirow{2}{*}{$\begin{array}{l}\text { Development } \\
\text { Region }\end{array}$} & \multirow{2}{*}{ County } & \multicolumn{3}{|c|}{ Permanent emigrants } \\
\hline & & Total & Men & Women \\
\hline \multirow{6}{*}{ NORTH-WEST } & Bihor & 176 & 84 & 92 \\
\hline & Bistriţa-Năsăud & 219 & 96 & 123 \\
\hline & Cluj & 351 & 156 & 195 \\
\hline & Maramureş & 273 & 123 & 150 \\
\hline & Satu Mare & 218 & 90 & 128 \\
\hline & Sălaj & 64 & 28 & 36 \\
\hline \multirow{6}{*}{ NORTH-EAST } & Bacău & 434 & 181 & 253 \\
\hline & Botoşani & 186 & 84 & 102 \\
\hline & laşi & 542 & 222 & 320 \\
\hline & Neamţ & 289 & 109 & 180 \\
\hline & Suceava & 253 & 108 & 145 \\
\hline & Vaslui & 260 & 111 & 149 \\
\hline \multirow{4}{*}{ WEST } & Arad & 286 & 112 & 174 \\
\hline & Caraş-Severin & 293 & 131 & 162 \\
\hline & Hunedoara & 290 & 135 & 155 \\
\hline & Timiş & 599 & 262 & 337 \\
\hline \multirow{6}{*}{ CENTER } & Alba & 161 & 77 & 84 \\
\hline & Braşov & 421 & 169 & 252 \\
\hline & Covasna & 65 & 21 & 44 \\
\hline & Harghita & 89 & 48 & 41 \\
\hline & Mureş & 254 & 113 & 141 \\
\hline & Sibiu & 355 & 165 & 190 \\
\hline \multirow{3}{*}{ SOUTH-WEST OLTENIA } & Dolj & 260 & 119 & 141 \\
\hline & Gorj & 69 & 24 & 45 \\
\hline & Mehedinţi & 92 & 32 & 60 \\
\hline
\end{tabular}


Babucea AG. et al.: A territorial analysis of the Gender Differences in Romanian...

\begin{tabular}{|c|c|c|c|c|}
\hline \multirow{4}{*}{$\begin{array}{l}\text { Development } \\
\text { Region }\end{array}$} & \multirow{2}{*}{ County } & \multicolumn{3}{|c|}{ Permanent emigrants } \\
\hline & & Total & Men & Women \\
\hline & Olt & 162 & 64 & 98 \\
\hline & Vâlcea & 98 & 36 & 62 \\
\hline \multirow{7}{*}{ SOUTH MUNTENIA } & Argeş & 175 & 79 & 96 \\
\hline & Călăraşi & 132 & 50 & 82 \\
\hline & Dâmboviţa & 211 & 98 & 113 \\
\hline & Giurgiu & 92 & 41 & 51 \\
\hline & lalomiţa & 92 & 34 & 58 \\
\hline & Prahova & 283 & 109 & 174 \\
\hline & Teleorman & 229 & 110 & 119 \\
\hline \multirow{6}{*}{ SOUTH-EAST } & Brăila & 167 & 67 & 100 \\
\hline & Buzău & 134 & 48 & 86 \\
\hline & Constanţa & 444 & 171 & 273 \\
\hline & Galaţi & 418 & 168 & 250 \\
\hline & Tulcea & 147 & 72 & 75 \\
\hline & Vrancea & 171 & 64 & 107 \\
\hline \multirow{2}{*}{ ILFOV-BUCHAREST } & Ilfov & 133 & 56 & 77 \\
\hline & Bucharest & 1664 & 709 & 955 \\
\hline ROMANIA & Total & 11251 & 4776 & 6475 \\
\hline
\end{tabular}

Source: Data available on Tempo Online database, www.insse.ro

Regarding figure 6 it is noticed that permanent emigration density function has differences by gender.To test if the variables considered, permanent emigrants both for women and men have normal distributions, for the year 2014, was appealed the Kolmogorov - Smirnov statistically test (K-S) by using SPSS procedure.Sig. values K-S test, respectively 0.208 for men permanent emigrants and 0,224 for women permanent emigrants, in 2014 at the county level, higher than 0.05 indicate that the both variables have a normal distribution of data. (Table 10). The result was to retain the null hypothesis for both distributions.

Table 10 Tests of Normality

\begin{tabular}{|l|r|r|r|r|r|r|}
\hline & \multicolumn{3}{|c|}{ Kolmogorov-Smirnov } & \multicolumn{3}{|c|}{ Shapiro-Wilk } \\
\cline { 2 - 7 } & Statistic & df & Sig. & Statistic & \multicolumn{1}{c|}{ df } & \multicolumn{1}{c|}{ Sig. } \\
\hline Permanent_Emigrants_Men &, 208 & 42 &, 000 &, 595 & 42 &, 000 \\
\hline Permanent_Emigrants_Women &, 224 & 42 &, 000 &, 592 & 42 &, 000 \\
\hline
\end{tabular}

a. Lilliefors Significance Correction

To have a graphic picture and having a visualization of differences between empirical and theoretical distribution have used the histogram. 
Babucea AG. et al.: A territorial analysis of the Gender Differences in Romanian...

Figure 6. Counties distributions on permanent emigrants - men and women, in 2014
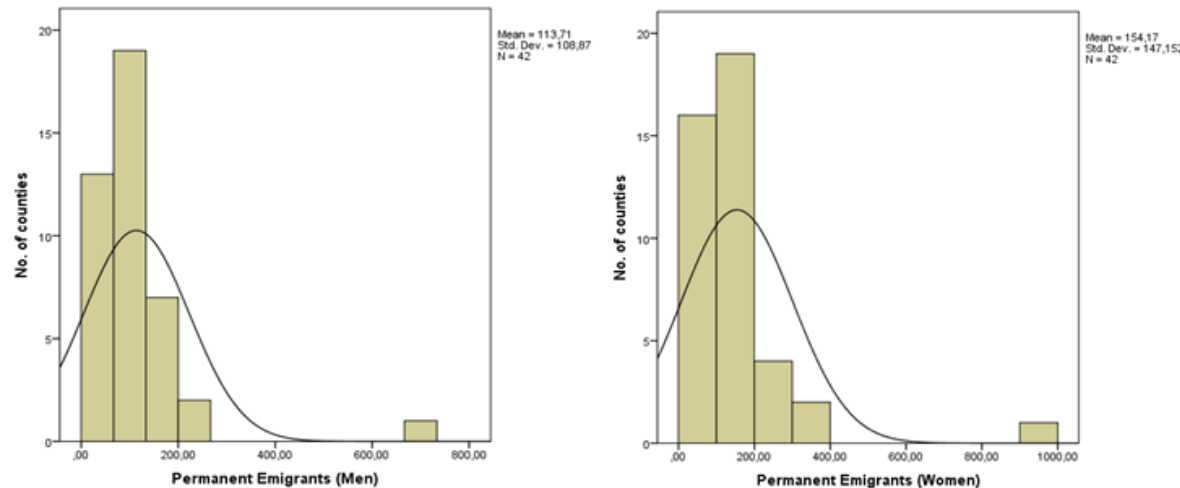

Distribution of counties by women indicates an average and a dispersion that are higher than for men population. The average for women permanent emigrants by county in 2014 is 154,17, while the for men permanent emigrants is 113,71 . In the same time, the standard deviation is equal to 147,152 for female permanent emigrants and 108,87 for male permanent emigrants.

Table 11 Descriptives

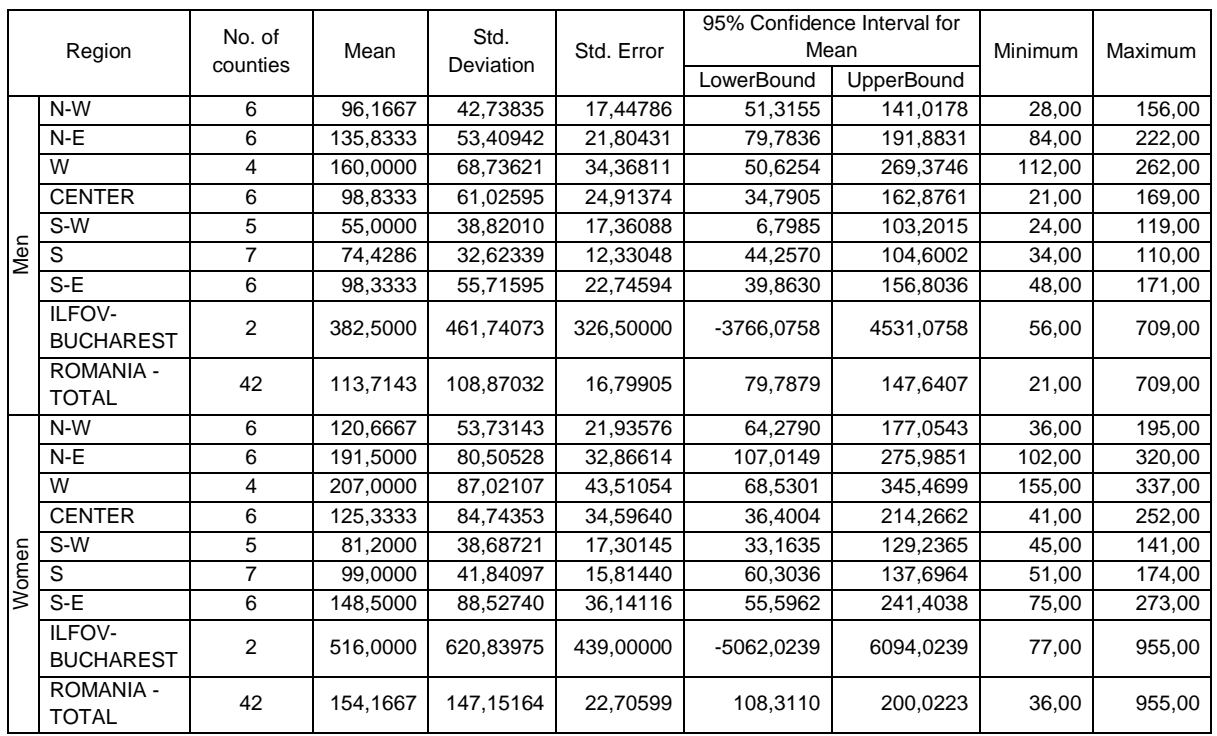

Source:authors' data processing based on National Institute of Statistics, Romania, tempo online 
Babucea AG. et al.: A territorial analysis of the Gender Differences in Romanian...

Table 12 gives Levene test results regarding the similarity of variance. As this test is significant, the significance is $p=0.000$, variances are homogeneous.

Table 12 Test of Homogeneity of Variances

\begin{tabular}{|l|r|r|r|l|}
\hline & \multicolumn{1}{|c|}{ Levene Statistic } & \multicolumn{1}{|c|}{ df1 } & \multicolumn{1}{c|}{ df2 } & \multicolumn{1}{l|}{ Sig. } \\
\hline Men & 41,546 & 7 & 34 &, 000 \\
\hline Women & 38,503 & 7 & 34 &, 000 \\
\hline
\end{tabular}

Source: authors' data processing based on National Institute of Statistics, Romania, tempo online

The results of analysis of variance, ANOVA are presented in the following table for variables permanent emigrants both men and women. $F$ ratio is significant in both cases.

Table 13. ANOVA

\begin{tabular}{|l|l|c|r|c|c|c|}
\hline \multicolumn{2}{|c|}{} & $\begin{array}{c}\text { Sum of } \\
\text { Squares }\end{array}$ & Df & $\begin{array}{c}\text { Mean } \\
\text { Square }\end{array}$ & F & Sig. \\
\hline \multirow{3}{*}{ Men } & BetweenGroups & 188632,524 & 7 & 26947,503 & 3,081 &, 013 \\
\cline { 2 - 7 } & WithinGroups & 297330,048 & 34 & 8745,001 & & \\
\cline { 2 - 8 } & Total & 485962,571 & 41 & & & \\
\hline \multirow{3}{*}{ Women } & BetweenGroups & 341213,367 & 7 & 48744,767 & 3,032 &, 014 \\
\cline { 2 - 7 } & WithinGroups & 546584,467 & 34 & 16076,014 & & \\
\cline { 2 - 8 } & Total & 887797,833 & 41 & & & \\
\hline
\end{tabular}

Source: authors' data processing based on National Institute of Statistics, Romania, tempo online

This means that there are significant differences at the level of regions and between regions and within them, at the counties level, regarding permanent emigrants, men or women.

\section{Conclusions}

The work carried out a statistical evaluation of regional differences at the regional level focusing on permanent emigration from Romania in terms of gender differences. Data considered are for the period 1993-2014. The study results showed that there was a decrease in dynamic manifestation permanent migration as a whole, but an increase in female migration in the period considered. To achieve this objective, we measured the concentration of permanent emigration in the year 2014 for both women and men noticing the differences in the 8 regions. These differences, although insignificant, can be explained by the action of specific factors such as the level of development of the departure region of the emigrants. It was identified regions in which 
Babucea AG. et al.: A territorial analysis of the Gender Differences in Romanian...

migration had an atypical manifestation for both women and men. The analysis of intra and inter-regional variation distinguish significant differences at the level of regions and between regions and within them, at the counties level both for men and women permanent emigrants. Regional economic development affects the profile of emigration, by gender, by regions or by counties, in Romania in 2014.

\section{References}

Andreescu, G. (2005), Schimbări în harta etnică a României. Centrul de Resurse pentru Diversitate Etno - culturală.

Babucea, A.G. (2010), Analiza datelor-Metode statistice avansate, Editura Universitaria, Craiova.

Dănăcica, D. (2010), Characteristics of Migration in Romania. Annals-Economy Series, 2, 189-200;

Frunză, R., Maha, L.G., Mursa, C.G., (2009). Reasons and Effects of the Romanian Labour Force Migration in European Union Countries, CES Working Papers, I, (2), 37-62;

Ghizdeanu, I., Răbonţu I. C., (2016). Trends in Using the Labour Force Subsequent to the Crisis, Annals of the "Constantin Brâncuşi” University of Târgu Jiu, Economy Series, Issue 3/2016, 10-21;

Jaba, E., (Ed.). (2002). Statistică, Ediţia a II-a, Editura Economică, Bucureşti.

Lorenz, M. O. (1905). Methods of Measuring the Concentration of Wealth. Publications of the American Statistical Association. Vol. 9, No. 70, 209-219.

Lucas, R. E. (2004). International migration regimes and economic development. Report for the expert group on development issues (EGDI), Swedish Ministry of Foreign Affairs;

Pociovălișteanu, M.D, Dobrescu, E.M., (2014). The Impact of Migration on Romania's Economical and Social Development, Annals of the "Constantin Brâncuşi” University of Târgu Jiu, Economy Series, Issue 1/2014, 264-267;

Pomohaci, C., Pârlea, D., (2008). Analiza datelor, Ediţiaa II-a, Editura Fundaţiei România de Mâine, Bucureşti;

Roman, M., Voicu C., (2010).Câteva efecte socio-economice ale migraţiei forţei de muncă asupra ţărilor de emigraţie. Cazul României, Economie teoretică şi aplicată. Volumul XVII, No. 7(548), 50-65;

Săvoiu, G., Crăciuneanu, V., Țaicu . (2010). A New Method Of Statistical Analysis Of Markets'Concentration or Diversification, Romanian Statistical Review no. 2/2010, Economic and financial statistics;

Zaharia, M., Enăchescu D., Bălăcescu A., (2014). Evolutions of Employment and Turnover in Services in EU, Industrija, Vol.42, No.2, 2014, 21-34. 